\title{
Improved Corrosion Resistance of Galvanized Steel with a Zinc Phosphate Coating in Alkaline Solution
}

\author{
De-lin Lai ${ }^{1, *}$, Yan-bin Jiang ${ }^{1}$, Yan-qi Wang ${ }^{2}$, Gang Kong ${ }^{2}$, Chun-shan Che ${ }^{2}$ \\ ${ }^{1}$ School of Chemistry and Chemical Engineering, South China University of Technology, Guangzhou \\ 510640, China; \\ ${ }^{2}$ School of Materials and Science Engineering, South China University of Technology, Guangzhou \\ 510640, China;) \\ *E-mail: flyaaa01@163.com
}

doi: $10.20964 / 2020.06 .76$

Received: 3 February 2020 / Accepted: 7 April 2020 / Published: 10 May 2020

\begin{abstract}
The corrosion activity of a zinc phosphate coating (ZP layer) on galvanized steel (GS) in alkaline solution in the presence of $\mathrm{Ca}^{2+}$ was investigated using open-circuit potential (OCP), potentiodynamic polarization (PDP) and electrochemical impedance spectroscopy (EIS) techniques. The results showed that, compared to that for the bare GS, the phosphate-coated GS presented a robust resistance to corrosion in a saturated $\mathrm{Ca}(\mathrm{OH})_{2}$ solution with/without $0.5 \mathrm{M}$ chloride. The GS pretreated with the phosphate coating was conducive to suppressing the rapid dissolution of the zinc layer and hydrogen evolution in the alkaline solution. The presence of $\mathrm{Ca}^{2+}$ in alkaline solution was beneficial to inhibit the dissolution of the ZP layer by precipitating calcium hydroxyzincate $\left.\left(\mathrm{Ca}\left(\mathrm{Zn}(\mathrm{OH})_{3}\right)\right)_{2} \cdot 2 \mathrm{H}_{2} \mathrm{O}\right)$ and hydroxyapatite $\left(\mathrm{Ca}_{10}\left(\mathrm{PO}_{4}\right)_{6}(\mathrm{OH})_{2}\right)$ at the corroding interface to form an effective barrier film.
\end{abstract}

Keywords: galvanized coating; phosphate coating; alkaline corrosion

\section{$\underline{\text { FULL TEXT }}$}

(C) 2020 The Authors. Published by ESG (www.electrochemsci.org). This article is an open access article distributed under the terms and conditions of the Creative Commons Attribution license (http://creativecommons.org/licenses/by/4.0/). 